\author{
Marek Szafrański \\ Dr inż. \\ Politechnika Gdańska, Wydział \\ Inżynierii Lądowej i Środowiska, \\ Katedra Transportu Szynowego i Mostów \\ mszafran@pg.edu.pl
}

DOI: 10.35117/A_ENG_19_10_02

\title{
The influence of railway vehicle modeling approach on the dynamic response of a bridge span
}

\begin{abstract}
The paper presents the results of numerical analysis and in-situ measurements of two railway bridge spans subjected to an action of moving vehicles. The railway vehicle is introduced using four simplified load models: series of concentrated forces, series of lumped masses and series of single-mass and two-mass oscillators. Numerical simulations are performed using FE method. The dynamic parameters of the vehicle and the bridge models are determined on the basis of modal identification results of existing structures - EN57 traction unit and steel bridges of 10 and $30 \mathrm{~m}$ theoretical span length. The vertical displacements and accelerations of the mid-span are analysed. The numerical results are referred to the results of in-situ measurements performed under operating conditions. A qualitative and quantitative comparison is made for all load models and bridge spans under analysis in the forced vibration range.
\end{abstract}

Keywords: Railway bridges; Railway loads; Vehicle-bridge dynamic interaction

\section{Introduction}

The issue of railway vehicle movement on the bridge span is a complex research question, e.g. $[2,10]$, and in the case of high-speed lines it becomes crucial due to increased safety requirements and passenger comfort. During the movement of a railway vehicle on the bridge span, we deal with a mutually coupled dynamic system in which the transfer of forces and interactions between the vehicle and the bridge structure takes place through the rail surface and is induced at the wheel and rail contact. The magnitude of these impacts is influenced, among others traffic speed and technical condition of the railway track [14]. Accurate analysis of the phenomenon requires consideration of several issues in the field of railway vehicle mechanics, railway track, bridge construction, as well as knowledge of the real mechanical parameters of these systems. This causes basic difficulty in dynamic modeling, which is why in the analysis of bridge structures simplifications are often adopted, including those regarding loads and railway surface, e.g. [12, 16, 17].

The history of the problem of load movement along the bridge span dates back to the first half of the 19th century [20]. A turning point was the launch in 1964 of Japan's first highspeed railway line (KDP). Since then, the high intensity of research has been observed, and the practical conclusions drawn from them contribute to the development of KDP technology, thereby improving rail traffic safety.

This work presents the results of dynamic analyzes of two bridge spans loaded with a moving railway vehicle. The research question is to assess the impact of the degree of simplification of the vehicle model on the dynamic response of the bridge span in terms of vertical displacements and accelerations. The assessment was based on numerical simulations and in-situ studies. The vehicle models were adopted based on the construction system of the 
EN57 series traction unit [4]. The stream of concentrated forces, a stream of concentrated masses and streams of one- and two-mass oscillators were considered. The first model is used in design practice, e.g. [23], the second additionally takes into account load inertia, e.g. [11], the last two models allow an analysis of load interaction and bridge structure, e.g. [9, 22]. The analyzed bridge spans are beam systems with relatively simple structures. The first of these is the KO30 steel unloading bay with box section and direct rail fastening. The second is a steel girder span of the bridge over the Radunia river in Gdańsk with an open roadway. Structural simplicity and the lack of bedding eliminates several unknowns that are difficult to identify, making it easier to compare and evaluate simulation results. An important stage of the analysis is the validation of numerical models based on the results of modal identification of real structures - both rolling stock and bridge spans. Modal parameters (vibration frequencies, vibration forms, damping numbers) were identified based on free responses using the ERA (Eigensystem Realization Algorithm) [8] and PP (Peak-Picking) [1] algorithms. The evaluation of the obtained numerical solutions was based on the results of operational tests of both spans in the field of forced vibrations. Displacements and accelerations of the spans were measured during the travels of EN57 units.

\section{Railway load models}

Railway load models were defined based on the EN57 series traction unit. The units consist of control cars (R) and engine cars $(\mathrm{S})$ in various configurations. Four ways of mapping the vehicle in the form of concentrated forces stream, concentrated mass stream and streams of one- and two-mass oscillators were considered (Fig. 1).

A load stream moves along each rail with the wheelbase of wheelsets and with pressures (masses) per wheel. The adopted markings are: $P_{S}, P_{R}-$ weight of the control and motor car, $M_{S}, M_{R}$ - the total mass of the motor and control car, $M_{S 1}, M_{R l}$ - sprung mass of the motor and control car in the dual-mass oscillator model, $M_{S 2}, M_{R 2}-$ unsprung mass (four wheelsets) of the motor and control car in the dual-mass oscillator model, $k_{S}, c_{S}, k_{R}, c_{R}-$ stiffness and damping coefficients of the springs in the single-mass oscillator model for the $\mathrm{S}$ and $\mathrm{R}$ wagons respectively, $k_{S 1}, c_{S 1}, k_{R 1}, c_{R 1}$ - stiffness and damping coefficients of the springs in the dual-mass oscillator model for the $\mathrm{S}$ and $\mathrm{R}$ wagons respectively. 




1. The considered mechanical models of railway load: (a) the scheme of the basic system of the EN57 unit, (b) the stream of concentrated forces, (c) the stream of concentrated masses,

(d) the stream of single-mass oscillators, (e) the stream of dual-mass oscillators

Symmetrical weight distribution was assumed in each of the wagons. In the single-mass oscillator model, the total mass was assumed to be sprung. Independent masses of wheelsets were separated in the dual-mass oscillator model. The dynamic parameters of the springs were defined based on the modal identification wagon of the EN57 unit. For this purpose, tests were carried out involving the impulse excitation and measurement of the free wagon response using the wedge method - Fig. 2a. Research methodology, adopted assumptions and results of modal identification are presented in the paper [18].

For the considered oscillator models, $k_{i}$ stiffness and damping coefficients $c_{i}$ were determined based on identified global modal parameters (frequency $f$ and damping number $\xi$ ) of the increased vertical form of vibrations (Fig. $\mathbf{2 b}$ and $\mathbf{2 c}$ ):

$$
k_{i}=\frac{(2 \pi f)^{2} M_{i}}{8}, c_{i}=\frac{\xi c_{i}^{k r}}{8}=\frac{\xi 2 M_{i}(2 \pi f)}{8},
$$

where $c_{i}^{k r}$ means critical attenuation, however, and should be understood as $\mathrm{R}, \mathrm{S}$ (single-mass oscillator model) and R1, S1 (dual-mass oscillator model). The criterion for the correctness of the model definition was the compliance of global modal parameters obtained from measurements (identification) and the numerical solution (own problem). 



2. Tests of the EN57 unit wagon: (a) test thresholds for excitation of vibrations, (b) location of sensors measuring vertical acceleration of the box, (c) free response of the box (vertical vibrations) - comparison of measured and theoretical signals (ERA) for the identified frequency $f=2,03 \mathrm{~Hz}$ and attenuation numbers $\xi=0.0497$

The dynamic parameters of individual load models are summarized in Table 1. The weight of the wagons also includes the mass of MP passengers, assuming their number equal to the number of seating positions. The weight of one passenger was equal to $80 \mathrm{~kg}$.

Tab. 1. Mechanical parameters of the EN57 unit for the considerated load models

\begin{tabular}{|c|c|c|c|}
\hline \multirow{2}{*}{\multicolumn{2}{|c|}{$\begin{array}{l}\text { Type of } \\
\text { parameter }\end{array}$}} & \multicolumn{2}{|c|}{ Parameter value } \\
\hline & & Car $\mathrm{R}$ & Car S \\
\hline$M_{R} / M_{S}$ & {$[\mathrm{t}]$} & 34,00 & 57,00 \\
\hline $\begin{array}{c}M_{R 1} / \\
M_{S 1}\end{array}$ & {$[\mathrm{t}]$} & 28,720 & 50,12 \\
\hline $\begin{array}{c}M_{R 2} / \\
M_{S 2}\end{array}$ & {$[\mathrm{t}]$} & 5,28 & 6,88 \\
\hline$M_{p}$ & {$[\mathrm{t}]$} & 4,96 & 7,68 \\
\hline$k_{R} / k_{S}$ & {$[\mathrm{kN} / \mathrm{m}]$} & 690,74 & 1158,00 \\
\hline$k_{R 1} / k_{S 1}$ & {$[\mathrm{kN} / \mathrm{m}]$} & 583,47 & 1018,22 \\
\hline$c_{R} / c_{S}$ & $\begin{array}{c}{[\mathrm{kNs} /} \\
\mathrm{m}]\end{array}$ & 5,39 & 9,03 \\
\hline$c_{R 1} / c_{S 1}$ & $\begin{array}{c}{[\mathrm{kNs} /} \\
\mathrm{m}]\end{array}$ & 4,55 & 7,94 \\
\hline$k_{H}$ & {$[\mathrm{kN} / \mathrm{m}]$} & $\begin{array}{c}1,167 \times \\
10^{6}\end{array}$ & $\begin{array}{c}1,382 \times \\
10^{6}\end{array}$ \\
\hline$R$ & {$[\mathrm{~m}]$} & 0,47 & 0,47 \\
\hline
\end{tabular}

In the case of the single-mass oscillator model, the force variation in the spring was assumed as a measure of dynamic coupling between the vehicle and the bridge structure. In the dualmass oscillator model, elastic contact ties described by Hertz's law were used between the wheel and rail mass [7]:

$$
F_{i}=d_{H} u_{i}^{3 / 2},
$$

where $F_{i}[\mathrm{~N}]$ and $u_{i}[\mathrm{~m}]$ mean respectively the contact force and the vertical shortening between the $i$ th wheel and rail in the contact area, $d_{H}$ is the non-linear Hertz's stiffness coefficient $\left[\mathrm{N} / \mathrm{m}^{3 / 2}\right]$. Assuming that the shortenings are small, one can use linearized Hertz's stiffness $k_{H}[\mathrm{~N} / \mathrm{m}]$ as secant stiffness between zero value and static wheel pressure [5]: 


$$
k_{H}=\frac{d F_{i}}{d u_{i}}=\frac{3}{2} d_{H} u_{i}^{1 / 2}=\frac{3}{2} d_{H}{ }^{2 / 3} F_{i}^{1 / 3}=\frac{3}{2} G^{-1} F_{i}^{1 / 3} .
$$

Value $G=d_{H}{ }^{-2 / 3}\left[\mathrm{~m} / \mathrm{N}^{2 / 3}\right]$ means Hertz's susceptibility. In [6], the authors showed the dependence of the constant $G$ on the radius of the circle: $G=4.57 \mathrm{R}^{-0.149} \times 10^{-8}\left[\mathrm{~m} / \mathrm{N}^{2 / 3}\right]$ for the new wheel and $\mathrm{G}=3.86 \mathrm{R}^{-0.115} \times 10^{-8}\left[\mathrm{~m} / \mathrm{N}^{2 / 3}\right]$ for a worn wheel. In this work, as in [15], the average $G$ value was used in the calculations.

\section{Bridge spans models}

The first structure under analysis is the KO30 steel unloading span with a span of $30 \mathrm{~m}$ (Fig. 3a). The construction of the span was discussed in [24] together with the special abutment solution used in track 2 of PKP PLK, which enabled rail traffic to be operated at speeds of up to $60 \mathrm{~km} / \mathrm{h}$ during the construction of a road connection through the existing railway embankment in Gdańsk. In this thesis, the results discussed relate to the span built in the adjacent track No. 502 PKP SKM. In this case, the span was based on a standard solution (temporary abutments made of wooden sleepers and bridge cranes, see [24]).
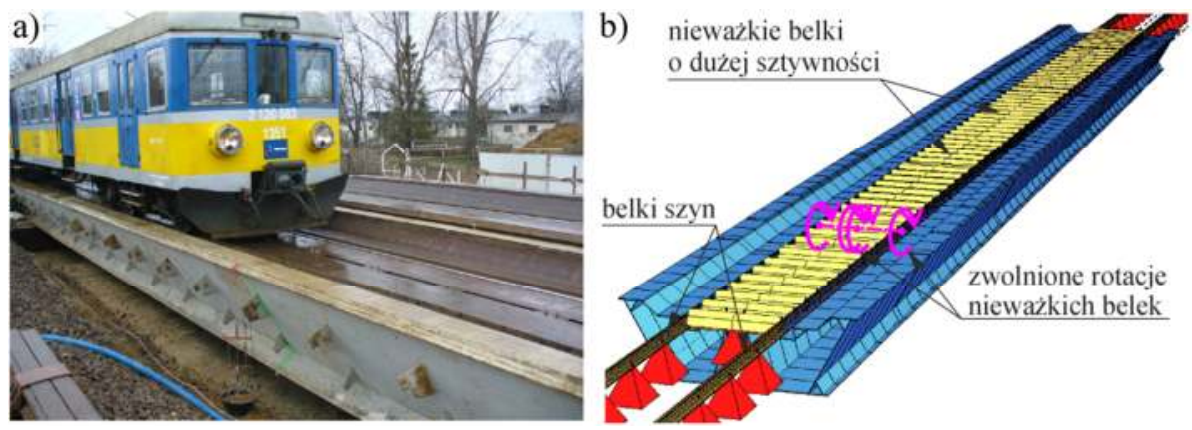

3. KO30 unloading span: (a) a structure built into the 502 PKP SKM track during operational tests, (b) visualization of the span numerical model (SOFiSTiK)

The numerical model of the span was made as a spatial, beam FEM model in SOFiSTiK [3]. As in [20], the elements were described on one axis of nodes lying on the transverse symmetry plane of the span. In this case, however, due to other load systems, the road track was mapped in the form of two independent rails (beam elements with 60E1 rail section and $1435 \mathrm{~mm}$ spacing) connected to the structure axis through weightless beams with very high rigidity $\left(E=205 \times 10^{9} \mathrm{MPa}\right)$. Rotational constraints around the longitudinal axis of beams were also released. The model is visualized in the figure $\mathbf{3 b}$.

The second structure is a girder bridge span of the bridge over the Radunia river in Gdańsk with the indirect and open roadway (Fig. 4a). The crossing consists of three freely supported spans, each with a span of $10.24 \mathrm{~m}$. The construction of the span is discussed in [21]. Extreme spans from Warsaw were subject to examination and analysis.
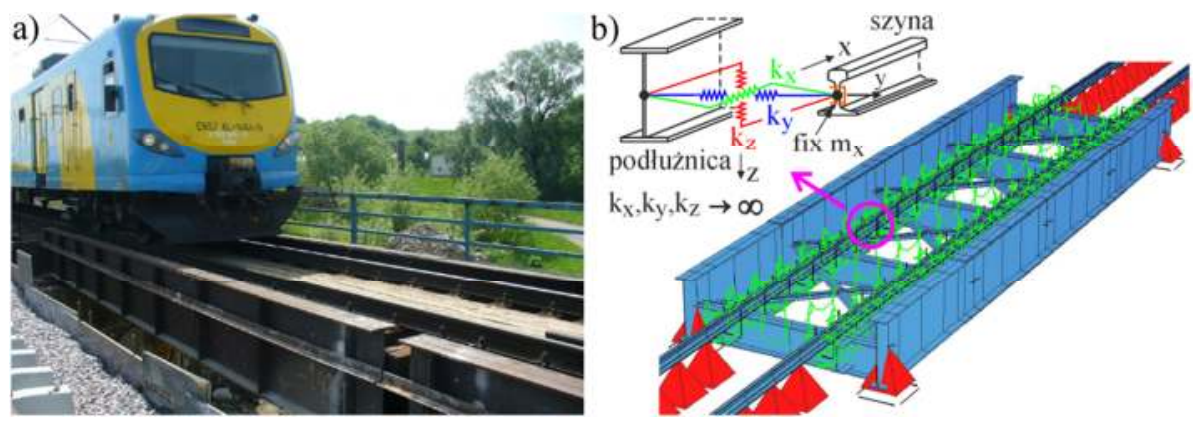

4. Bridge over the Radunia River in Gdansk: (a) external span during operational tests, (b) visualization of the numerical span model (SOFiSTiK) 
The FEM model was made of beam elements (Fig. 4b). In this case, the elements were described on the plane of the nodes, which was adopted at the level of the center of gravity of the main girders. Cross-sections of platform components and bracing were located on appropriate eccentrics. The open type of railway surface has been taken into account in a simplified manner. Only railway rails were mapped with beam elements. Their connection (backrest) with the longitudinals was carried out using elastic constraints of very high rigidity. Thus, the impact of the actual surface compliance on the simulation results was not considered.

\section{Test and numerical simulations results}

Operational tests were performed on both spans (see Figures 3a and 4a) aimed at: (a) validation of numerical models of spans based on free-response signals, (b) comparison of test results with the results of numerical simulations in the field of forced vibrations.

Validation of dynamic parameters of span models (mass, stiffness, damping) was carried out based on identified global modal parameters - frequency $\mathrm{f}$ and damping numbers $\xi$ (Table 2). ERA and PP modal identification techniques were used. The methodology and results of identification of the span of the bridge over the Radunia river are presented in [21]. Only the first own form and the corresponding modal parameters $f_{1}$ and $\xi_{1}$ were identified. The paper [20] discusses the methodology and results of identification of the KO30 bay of embedded track 2 of PKP PLK, for which four stable frequencies and damping numbers have been identified. An analogous procedure was taken for the structure in question at track 502 of PKP SKM. In this case, only the first form of bending vibrations was identified, and the differences in the obtained modal parameters (especially damping) are due to the different support conditions characterizing both structures (temporary wooden cages instead of reinforced concrete abutments and steel bearings).

Tab. 2. Modal parameters of the analyzed bridge spans

\begin{tabular}{|c|c|c|c|c|}
\hline \multirow{2}{*}{$\begin{array}{c}\text { Span / } \\
\text { Parameter }\end{array}$} & \multicolumn{2}{|c|}{ ERA, PP } & \multicolumn{2}{c|}{ FEM model } \\
\cline { 2 - 5 } & $f_{1}[\mathrm{~Hz}]$ & $\xi_{1}[-]$ & $f_{1}[\mathrm{~Hz}]$ & $\begin{array}{c}b \\
(\mathbf{C}=b \mathbf{K})\end{array}$ \\
\hline KO30 & 4,07 & 0,0117 & 4,06 & $9,150 \cdot 10^{-4}$ \\
Radunia & 22,18 & 0,0104 & 21,91 & $1,492 \cdot 10^{-4}$ \\
\hline
\end{tabular}

Stiffness and mass in span models were verified based on comparing the natural frequency (measured and obtained from solving the own problem) for the first form of bending vibrations. The damping model was adopted as the stiffness $\mathbf{C}=b \mathbf{K}$, in which the proportionality factor was calculated as $b=\xi_{l} / \pi f_{l}$.

Simulations of load travel over the bridge span were carried out in the SOFiSTiK program using the Newmark method (unconditionally stable variant). The vibration of the span center centers (Fig. 5) in the range of vertical displacements and accelerations around the static equilibrium position was considered. As a result of the convergence analysis, the integration steps were chosen as $\Delta t=0,004 \mathrm{~s}(\operatorname{span} \mathrm{KO} 30)$ and $\Delta t=0,002 \mathrm{~s}$ (span of the bridge over the Radunia river). he implemented procedure was verified in [19], considering a single concentrated force model and a single-mass oscillator moving along the Euler beam. In the case of concentrated forces model, calculations are made for subsequent load settings following the adopted integration step using information from the current and previous step. In the case of inertial models, additional interaction between the span and the vehicle is provided by visco-elastic contact bonds between the vehicle masses and the contact points of the track. For the concentrated mass model and dual-mass oscillators, the stiffness of said 
constraints corresponds to Hertz's linearized stiffness. In the case of single-mass oscillators, the bonds were given vehicle suspension characteristics. Visualizations of computational models for the two selected cases are shown in the figure $\mathbf{6}$.

a)

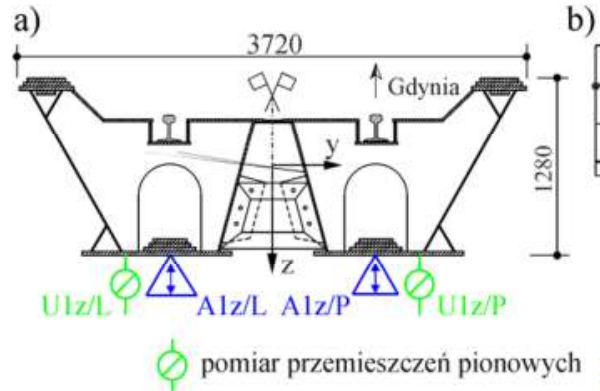

b)



5. Sensors and directions of span vibration measurement - cross-sections analyzed in the span centers: (a) KO30 span, (b) span of the bridge over the Radunia River

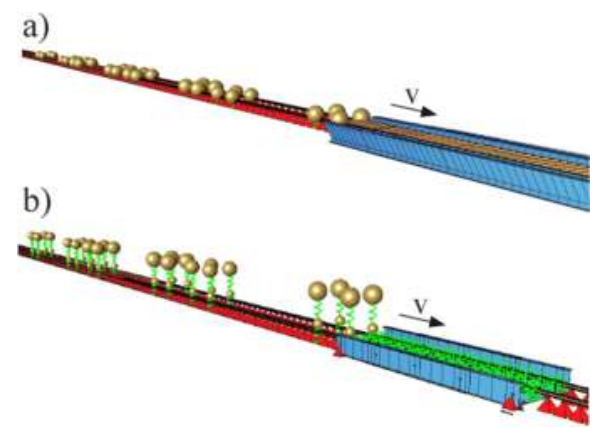

6. Visualizations of selected calculation models (SOFiSTiK): (a) the KO30 spans loaded with concentrated masses, (b) the span of the bridge over the Radunia river loaded with dual-mass oscillators

Figure 7 compares the time oscillation vibrations of the KO30 span obtained for the configuration of the RSSR rolling stock and the speed of $26 \mathrm{~km} / \mathrm{h}$. Figure 8 shows the analogous results for the bridge span over the Radunia river obtained for the configuration of the RSR rolling stock and the speed of $49 \mathrm{~km} / \mathrm{h}$. The guidelines of the standard [13] were applied when considering accelerations in the $0 \div 30 \mathrm{~Hz}$ band (KO30 span) and $0 \div 35 \mathrm{~Hz}$ (span of the bridge over the Radunia river). A frequently used indicator of quantitative signal comparison is the mean square (effective) value, which is a measure of average signal strength (RMS). RMS values were determined for acceleration signals in the range of forced vibrations, counted from the moment of entry of the load to its complete descent from the structure. In the case of the KO30 span, this time was $15.5 \mathrm{~s}$, while for the span of the bridge over the Radunia river, $5.3 \mathrm{~s}$. The comparison used is presented in the figure below 9. 

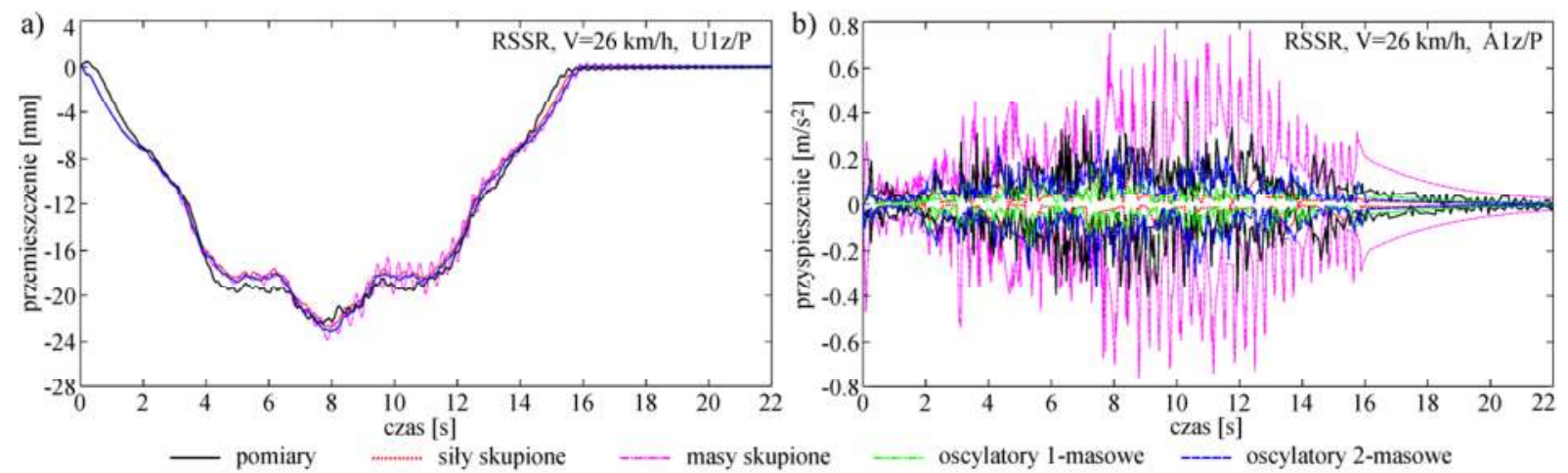

7. Vibrations of the KO30 span center - comparison of test results and numerical simulations for individual load models: (a) vertical displacements U1z/P, (b) vertical accelerations A1z/P
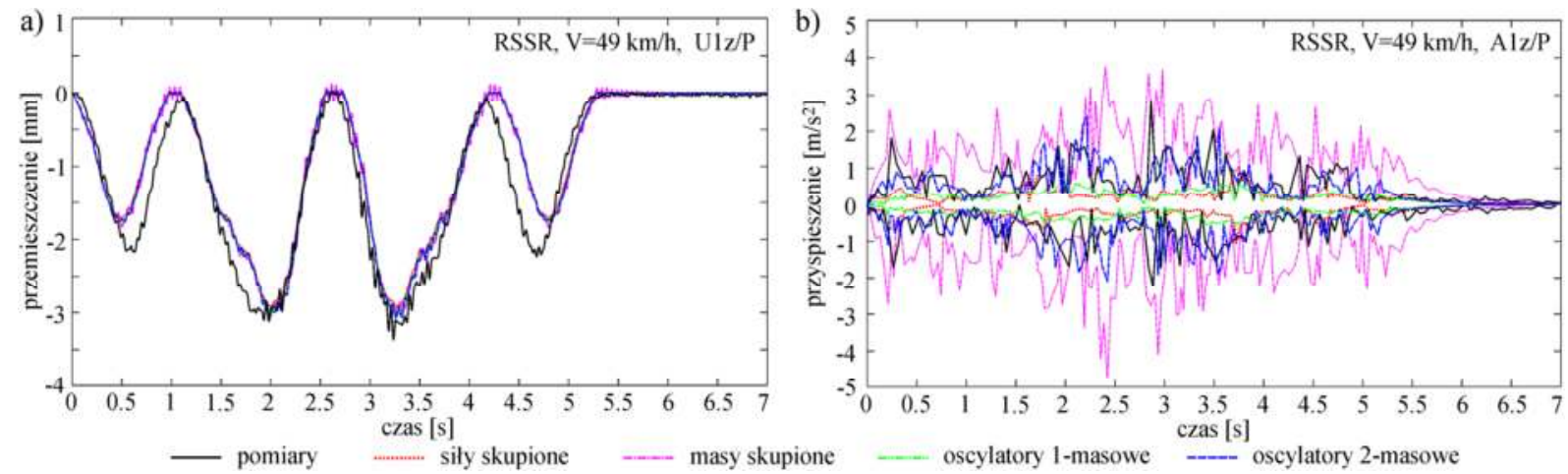

8. Vibrations of the bridge span center over the Radunia river - comparison of test results and numerical simulations for individual load models: (a) vertical displacement U1z/P, (b) vertical acceleration $\mathrm{A} 1 \mathrm{z} / \mathrm{P}$
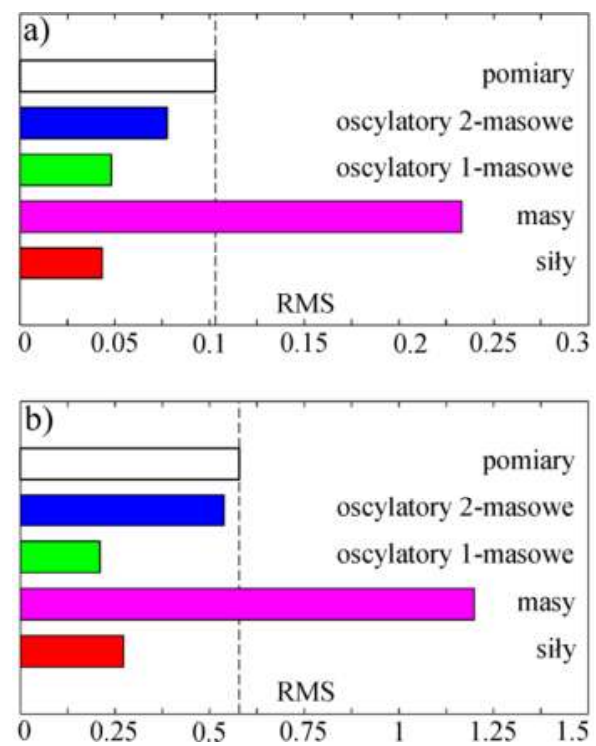

9. Average square values (RMS) of measured and numerical acceleration signals in the range of stimulated vibrations: (a) KO30 span, (b) span of the bridge over the Radunia river

\section{Discussion and conclusions}

Based on the research, the main conclusions can be drawn: 
- Objective dynamic analysis of railway bridges under moving loads requires the determination of real dynamic parameters of both spans and moving loads. The presented methodology for the definition of numerical models can be an effective way to objectify the results of dynamic analyzes.

- The method of mapping a rail vehicle in the analyzes of vehicle-span interaction significantly affects the results of the acceleration of the bridge span. A comparison of the results of tests and numerical simulations shows significant differences in the quantitative response of spans for the considered load models. At the same time, one can notice the general correctness of the results obtained for both cases of the analyzed structures.

- The omission of inertial forces of the load (concentrated forces model) has underestimated the acceleration amplitudes. On the other hand, the adoption of the entire vehicle mass as unsprung (concentrated mass model) resulted in double the response level. The vehicle sprung models have a stabilizing effect on the span vibrations, with the closest measured results obtained for the dual-mass oscillator model. The single-mass oscillator model significantly lowered the span response level.

- Analyzes of acceleration of railway bridge spans with similar construction systems and pavement types considered, require taking into account dynamic models of moving loads. An important element of these models is the unsprung mass of wheelsets. The remaining mass shall be taken as sprung, taking into account at least one degree of spring back.

- The vehicle mapping method does not significantly affect the values of global span displacements. The nature and level of response obtained for all considered models is similar and close to the measured values. In this respect, the concentrated forces model used in engineering practice gives results close to both sprung models. Only in the case of the concentrated mass model is visible an increased level of dynamic displacements (relative to quasi-static values) and a greater level of free vibration excitation (threshold effect). The concentrated mass model can, therefore, lead to overstated results when analyzing e.g. dynamic overload factors.

- Compliance of the maximum measured and theoretical displacements allow to conclude on the correct mapping of the geometry and stiffness of the analyzed spans and good estimation of the rolling stock mass. Only in the case of the bridge over the Radunia river are there some discrepancies in the extreme values of displacements caused by camshafts. A possible reason is the actual lack of symmetry in the distribution of the car construction mass and the underestimation of the mass of passengers (cargo), whose number on the tested section is variable and strongly dependent on the time of day.

The presented analyzes relate to relatively low speeds that were achieved by rolling stock during in-service tests. However, these studies are a key element enabling comparison and evaluation of simulation results, which was the purpose of this work. Certainly, analyzes carried out in a wider speed range and the expansion of vehicle models with further dynamic degrees of freedom (modal identification) would allow for a broader assessment of the phenomenon. An additional research question is the assessment of the impact of ballast or unconventional surfaces on the dynamic response of a bridge span, taking into account real dynamic characteristics and track geometric imperfections. These surfaces are currently dominant and the only ones acceptable for high-speed lines. The surface's vulnerability, good damping properties, and significant weight have a positive effect on the dynamics of bridge spans and reduce the magnitude of the interaction between the span and the railway vehicle. In turn, the geometrical inaccuracies of the track are a source of additional, often significant excitation of vibrations of both the span and the railway vehicle. 


\section{Source materials}

[1] Bendat J.S., Piersol A.G. Engineering Applications of Correlation and Spectral Analysis. John Wiley \& Sons, 1980.

[2] Bryja D., Hołubowski R., Gisterek I. Railroad vehicle modeling in probabilistic vibration analysis of a railway bridge with randomly fluctuating track ballast stiffness. 9th European Conference on Structural Dynamics, EURODYN 2014, 30th June - 2nd July 2014, 2737-2744.

[3] Catz C., Deinzer F., Maly S., Fink T. SOFiSTiK A.G., v.2014, www.sofistic.com, 08.2019.

[4] Domański E., Kowalczyk E., Skoniecki J. Elektryczne zespoły trakcyjne serii EW55 i EN57. WKiŁ, 1974.

[5] Esveld C. Modern railway track. MRT Productions, 1989.

[6] Jenkins H.H, Stephenson J.E., Clayton G.A., Morland H.W., Lyon D. The effect of track and vehicle parameters on wheel/rail vertical dynamic forces. Railway Engineering Journal, 3(1), 1974, 2-16.

[7] Johnson K.L. Contact mechanics. Cambridge University Press, 1985.

[8] Juang J.N., Pappa R.S. An eigensystem realization algorithm for modal parameter identification and model reduction. Journal of Guidance, Control and Dynamics, 8(5), 1985, 620-627.

[9] Klasztorny M. Analiza drgań belki mostowej przenoszącej jednorodny strumień obciążeń ruchomych. Archiwum Inżynierii Lądowej 36(3), 1990, 207-227.

[10] Klasztorny M. Dynamika mostów belkowych obciążonych pociągami szybkobieżnymi. WNT, 2005.

[11] Michaltsos G. T., Sophianopoulos D., Kounadis A. N. The effect of a moving mass and other parameters on the dynamic response of a simply supported beam. Journal of Sounds and Vibration, 191(3), 1996, 357-362.

[12] Oleszek R., Radomski W. Dynamic analysis of an existing arch railway bridge according to Eurocodes. Archives of Civil Engineering, LXII, 4/I, 2016, 99-117.

[13] PN-EN 1990 Eurokod. Podstawy projektowania konstrukcji. Załącznik A2: Zastosowanie do mostów. Polski Komitet Normalizacyjny, 2008.

[14] Podworna M. Współczynniki dynamiczne ugięć pionowych w analizie numerycznej belkowych mostów kolejowych. Przegląd Komunikacyjny, 9, 2017, 7-11.

[15] Podworna M. Dynamic response of steel-concrete composite bridges loaded by highspeed train. Structural Engineering and Mechanics 62(2), 2017, 179-196.

[16] Poprawa G., Pradelok S., Łaziński P., Rudzik A. Obiekty mostowe na liniach kolejowych dużych prędkości - studium przypadku. Inżynieria i Budownictwo, 11, 2014, 636-640.

[17] Ribeiro D., Calcada R., Delgado R. Dynamic analysis of Alcácer do Sal railway bridge. EURODYN 2005. 4-7th September 2005, 1661-1667.

[18] Szafrański M. Oddziaływania taboru na mosty kolejowe przy zmiennych parametrach ruchu. Rozprawa doktorska, Politechnika Gdańska, 2014.

[19] Szafrański M. Vibration of the bridge under moving singular loads - theoretical formulation and numerical solution. Journal of Applied Mathematics and Computational Mechanics, 15(1), 2016, 169-180.

[20] Szafrański M. Dynamic analysis of the railway bridge span under moving loads. Roads and Bridges - Drogi i Mosty. 17, 2018, 299-316.

[21] Szafrański M. Dynamics of the small-span railway bridge under moving loads, MATEC Web Conf. 26210014 (2019) 1-8. 
[22] Szcześniak W., Ataman M., Zbiciak A. Drgania belki sprężystej wywołane ruchomym, liniowym oscylatorem jednomasowym. Roads and Bridges - Drogi i Mosty 1(2), 2002, 53-83.

[23] Żółtowski K., Kozakiewicz A., Romaszkiewicz T., Szafrański M., Madaj A., Falkiewicz R., Raduszkiewicz K., Redzimski K. Przebudowa mostu kolejowego przez rzekę Pilicę z przystosowaniem do dużych prędkości. Archiwum Instytutu Inżynierii Lądowej, 8, 2010, 289-299.

[24] Żółtowski K., Szafrański M., Kozakiewicz A. Zastosowanie istniejących przęseł odciążających typu mostowego dla prędkości eksploatacyjnych do $60 \mathrm{~km} / \mathrm{h}$. Mosty 2/2013, 24-27. 